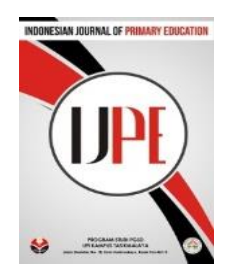

\title{
Pemikiran Kritis dapat dibentuk melalui Discovery Learning
}

\author{
Galih Yansaputra ${ }^{1}$, Rintis Rizkia Pangestika ${ }^{2}$ \\ PGSD Universitas Muhammadiyah Purworejo \\ *Corresponding author: intermilane90@gmail.com, rintisrizkia@gmail.com
}

Diterima 20 Agustus 2018; Direview 18 September 2018; Diterima 15 Oktober 2018

Diterbitkan online 28 Desember 2018

\begin{abstract}
Critical thinking is the personal basic skill. Nowadays everyone must have this skill to develop the way of thinking. It is how to organize small idea to be a discourse. In teaching learning, most students learning social science do not think about it. They prefer to getting high score by cheating. It means they do not pay attention for the process of how to develop their critical thinking. It happens on early-level student; elementary level. This study is descriptive- qualitative. It describes the global phenomena in with solving deep-problem. The problem statement are based on student. In this case, the researchers see they have no passion of the lesson. Some of them cannot follow the instruction. In this study explore how important the teacher's role in developing critical thinking, the effectiveness model of discovery learning. The result of the study the students are able to catch idea, compare, analyze, apply, reorganize, and conclude. In the other side, the teacher is not only be informative but also motivative and become facilitator for them to be active in learning-teaching process based on problem.
\end{abstract}

Keywords: Discovery Learning, Critical thinking.

Abstrak

Berfikir kritis merupakan kemampuan dasar yang harus dimiliki oleh setiap orang. Di era sekarang ini setiap orang dituntut untuk mengembangkan kemampuan berpikir kritisnya. Kemampuan mengorganisir terhadap suatu ide gagasan sebagian kecil dari kemampuan berfikir kritis. Dewasa ini sebagian siswa belajar IPS hanya untuk mendapatkan nilai yang bagus sehingga tak sedikit dari mereka mengambil jalan pintas yaitu meniru atau mencontek pekerjaan teman. Mereka hanya berpikir bagaimana caranya mendapatkan nilai yang bagus tanpa ada rasa senang atau bermakna. Hal ini juga dialami siswa-siswi SD. Penelitian ini menggunakan metode deskriptif kualitatif dimana menggambarkan sebuah fenomena global dengan penyelesaian masalah secara mendalam. Masalah yang dihadapi oleh guru ketika dalam pembelajaran yaitu sebagian besar siswa kurang bersemangat mengikuti ceramah dan perintah guru, di sesi tanya jawab sedikit siswa yang aktif menjawab pertanyaan guru. Penelitian ini memaparkan seberapa penting peran guru dan keefektifan model belajar Discovery Learning guru. Hasil dari penelitian model belajar ini siswa dapat melakukan berbagai kegiatan menghimpun informasi, membandingkan, mengkategorikan, menganalisis, mengintegrasikan, mereorganisasikan bahan serta membuat simpulan. Dalam studi ini guru tidak hanya informatif, namun juga sebagai motivatif dan guru dapat menjadi fasilitator yang mengarahkan siswa agar terlibat secara aktif dalam seluruh proses pembelajaran dengan diawali pada masalah yang berkaitan dengan konsep yang dipelajari.

Kata Kunci: Discovery learning, Berfikir kritis.

\section{PENDAHULUAN}

Manusia tidak bisa lepas dari pendidikan.

Pendidikan merupakan salah satu sector penting dalam pembangunan di setiap negara. Menurut Undang-Undang No. 20 Tahun 2003 tentang Sisdiknas dalam pasal 1 disebutkan bahwa pendidikan merupakan usaha sadar dan terencana untuk mewujudkan suasana belajar dan proses pembelajaran agar peserta didik secara aktif mengembangkan potensi dirinya

untuk memiliki kekuatan spiritual keagamaan, pengendalian diri, kepribadian, kecerdasan, akhlak mulia, serta keterampilan yang diperlukan dirinya, masyarakat, mengembangkan segala potensi yang dimiliki peserta didik melalui proses pembelajaran. Dalam pasal 4 dijelaskan bahwa peserta didik adalah anggota masyarakat yang berusaha 
mengembangkan potensi diri melalui proses pembelajaran yang tersedia pada jalur, jenjang, dan jenis pendidikan tertentu.

Dengan demikian pendidikan adalah segala daya upaya dan semua usaha untuk membuat masyarakat dapat mengembangkan potensi peserta didik agar memiliki kekuatan spiritual keagamaan, pengendalian diri, berkepribadian, memiliki kecerdasan, berakhlak mulia, serta memiliki keterampilan yang diperlukan sebagai anggota masyarakat dan warga negara.

Guru merupakan kunci keberhasilan dalam proses pembelajaran. interaksi positif antara guru dengan peserta didik dalam pembelajaran sangat berpengaruh dalam hasil belajar mengajar. Oleh karena itu guru perlu memperhatikan kebutuhan, keinginan dan memberikan dorongan kepada peserta didik. Keinginan keamanan dan semangat siswa merupakan hal yang sangat penting bagi keberhasilan pembelajaran di sekolah. Semangat merupakan pendorong bagi siswa untuk mengetahui dan meningkatkan rasa ingin tahu siswa sehingga siswa mau lebih rajin belajar sehingga akan mendapatkan apa yang menjadi keinginannya. Minat dan semangat siswa sangat berperan penting dalam pencapaian tujuan akhir pembelajaran, maka siswa akan mengerti dan paham segala yang dipelajarinya sehingga prestasi siswa akan lebih meningkat dari sebelumnya.

Setiap model pembelajaran mempunyai kelebihan dan kekurangan, sehingga seorang guru dapat memilih salah satu model pembelajaran yang sesuai dengan materi yang diberikan, jika perlu menggabungkan beberapa model pembelajaran. Pemilihan model pembelajaran yang dilakukan oleh guru bertujuan agar tercipta iklim dan pelayanan terhadap kemampuan, potensi, minat, bakat, dan kebutuhan peserta didik yang beragam sehingga terjadi interaksi yang optimal antara guru dengan siswa serta antara siswa dengan siswa. Pemilihan model pembelajaran itu diharapkan dapat mencapai tujuan pembelajaran secara maksimal. Ketercapaian tujuan dapat diketahui tercapainya standar ketuntasan belajar.

Dewasa ini sebagian siswa belajar IPS hanya untuk mendapatkan nilai yang bagus sehingga tak sedikit dari mereka mengambil jalan pintas yaitu meniru atau mencontek pekerjaan teman. Mereka hanya berpikir bagaimana caranya mendapatkan nilai yang bagus tanpa ada rasa senang atau bermakna Hal ini juga dialami siswa-siswi SD MIM Krendetan. Peneliti melihat bahwa mereka kurang semangat saat diberi pertanyaaan oleh guru, walaupun ada yang menjawab hanya anak itu-itu saja. Disinilah peran guru sebagai pembimbing sangat dibutuhkan. Hal ini menuntut pengajar untuk bersikap lebih objektif dan profesional dalam melaksanakan tugasnya. Masalah rendahnya nilai IPS tadi.

Aplikasi dari model Discovery Learning guru berperan sebagai pembimbing dengan memberikan kesempatan kepada siswa untuk 
belajar secara aktif, sebagaimana pendapat guru harus dapat membimbing dan mengarahkan kegiatan belajar siswa sesuai dengan tujuan (Sardiman, 2005:145). Kondisi seperti ini ingin merubah kegiatan belajar mengajar yang teacher oriented menjadi student oriented. Hal yang menarik dalam pendapat Bruner yang menyebutkan: hendaknya guru harus memberikan kesempatan muridnya untuk menjadi seorang problem solver, seorang scientis, historin, atau ahli matematika. Dalam model Discovery Learning bahan ajar tidak disajikan dalam bentuk akhir, siswa dituntut untuk melakukan berbagai kegiatan menghimpun informasi, membandingkan, mengkategorikan, menganalisis, mengintegrasikan, mereorganisasikan bahan serta membuat kesimpulan-kesimpulan sehingga membuat anak mampu berfikir kritis.

\section{METODE PENELITIAN}

Jenis metode yang digunakan dalam penelitian ini adalah pengembangan atau Research and Development (R\&D).

Penelitan ini bertujuan untuk mengetahui tingkat keberhasilan berfikir kritis melalui Discovery Learning yang valid, efektif dan praktis. Langkah-langkah pelaksanaan strategi penelitian dan pengembangan yang dilakukan untuk menghasilkan produk tertentu dan untuk menguji keefektifan produk yang dimaksud, adalah : a. Potensi dan masalah

Masalah juga bisa dijadikan sebagai potensi, apabila kita dapat mendayagunakannya. Sebagai contoh sampah dapat dijadikan potensi jika kita dapat merubahnya sebagai sesuatu yang lebih bermanfaat. Potensi dan masalah yang dikemukakan dalam penelitian harus ditunjukkan dengan data empirik. Masalah akan terjadi jika terdapat penyimpangan antara yang diharapkan dengan yang terjadi. Masalah ini dapat diatasi melalui R\&D dengan cara meneliti sehingga dapat ditemukan suatu model, pola atau sistem penanganan terpadu yang efektif yang dapat digunakan untuk mengatasi masalah tersebut.

b. Mengumpulkan Informasi

Produk pendidikan, terutama produk yang berbentuk model, program, sistem, pendekatan, software dan sejenisnya memiliki dasar-dasar konsep atau teori tertentu. Untuk menggali konsep-konsep atau teori-teori yang mendukung suatu produk perlu dilakukan kajian literatur secara intensif.

c. Desain Produk

Desain produk harus diwujudkan dalam gambar atau bagan, sehingga dapat digunakan sebagai pegangan untuk menilai dan membuatnya serta memudahkan fihak lain untuk memulainya. Desain sistem ini masih bersifat hipotetik karena efektivitasya belum terbukti, dan akan dapat diketahui setelah melalui pengujian-pengujian. 


\section{d. Validasi Desain}

Validasi produk dapat dilakukan dengan cara menghadirkan beberapa pakar atau tenaga ahli yang sudah berpengalaman untuk menilai produk baru yang dirancang tersebut. Setiap pakar diminta untuk menilai desain tersebut, sehingga selanjutnya dapat diketahui kelemahan dan kekuatannya. Validasi desain dapat dilakukan dalam forum diskusi.

e. Perbaikan Desain

Setelah desain produk, divalidasi melalui diskusi dengan pakar dan para ahli lainnya, maka akan dapat diketahui kelemahannya. Kelemahan tersebut selanjutnya dicoba untuk dikurangi dengan cara memperbaiki desain. Yang bertugas memperbaiki desain adalah peneliti yang mau menghasilkan produk tersebut.

\section{HASIL DAN PEMBAHASAN}

Hasil penilitian yang dipaparkan berdasarkan tahapan-tahapan pengembangan model milik Sugiyono. Metode pengembangan terdiri dari 5 tahap, yaitu; (1) primary investigation, (2) Design (perancangan), (3) Realization/Construction (realisasi/konstruksi) (4) Tes, evaluation and revision (Tes, evaluasi dan revisi) dan (5) Desiminasi (implementasi). Tujuan dari penelitian ini adalah mengembangkan desain perangkat pembelajaran IPS dengan model Problem Based Learning berbantuan peta konsep yang valid, efektif dan praktis.

Hasil penilaian kompetensi pedagogik dan angket respon guru yang diberikan setelah kegiatan pembelajaran diperoleh informasi bahwa respon guru memberikan respon positif terkait pembelajaran dengan menggunakan model discovery learning. Selain dari itu, penilaian dari guru lain beserta peneliti dengan menggunakan penilaian kompetensi pedagogik guru, menyatakan respon positif guru dalam hal mengajar. Data respon guru kemudian diuji dengan one sample $\mathrm{t}$ test untuk menguji batas yang ditentukan yaitu $75 \%$.

Berdasarkan dari hasil uji kepraktisan data yang diperoleh hasil yang positif atau baik. Berdasarkan hasil wawancara dengan guru kelas IV, pembelajaran IPS dengan model discovery learning sangat baik dan perlu diterapkan dalam pembelajaran sebagai salah satu metode yang dapat meningkatkan berfikir kritis siswa. Secara umum bahwa model discovery learning sangat tepat digunakan dalam pembelajaran IPS yang dianggap sebagian besar siswa merasa bosan karena bersifat hafalan menjadi materi yang dipelajari siswa dalam konsep kehidupan nyata serta mengasah kerja otak kanan dan otak kiri.

Pelaksanaan pembelajaran pada uji coba ini dilakukan dengan pendekatan langkahlangkah tindakan kelas. Selama kegiatan pembelajaran dilakukan pengamatan terhadap motivasi siswa, ketrampilan guru mengelola pembelajaran oleh pengamat. Di samping itu pengamat dan pembimbing memberi masukan untuk perbaikan lembar pengamatan. 
Selanjutnya penelitian dilakukan di SD MIM Krendetan untuk kelas IVA sebagai kelas eksperimen dan Kelas IVB sebagai kelas kontrol. Dari hasil lapangan menunjukkan hasil bahwa kelas eksperimen dari 29 siswa terdapat 24 siswa atau sekitar $80 \%$ yang berhasil mencapai KKM dengan rata-rata kelas 78,89. Sedangkan untuk kelas kontrol hanya terdapat 18 siswa atau sekitar $65 \%$ yang berhasil mencapai KKM dengan ratarata kelas 71,22. Berdasarkan penelitian proses pembelajaran dengan menggunakan perangkat pembelajaran yang berorientasi pada model pembelajaran discovery learning, menghasilkan pembelajaran yang efektif. Hal ini ditunjukkan dengan terpenuhi ketuntasan belajar. Oleh karena proses pembelajaran yang menggunakan perangkat pembelajaran yang berorientasi pada model pembelajaran discovery learning dapat menyebabkan siswa mudah memahami materi pembelajaran, merasa senang dan berminat mengikuti kembali proses pembelajaran yang menggunakan model tersebut serta dapat mencapai tujuan pembelajaran, maka dapat disimpulkan model pembelajaran discovery learning menghasilkan pembelajaran yang efektif.

\section{a. Penilaian Berfikir Kritis}

Berfikir Kritis dalam pembelajaran yang menggunakan perangkat pembelajaran dengan model discovery learning di kelas eksperimen eksperimen menunjukkan peningkatan. Hal ini dapat dilihat berdasarkan data analisis pembanding berfikir kritis awal siswa kelas eksperimen dan kontrol dengan hasil penilaian sebagai berikut:

Tabel 1

\begin{tabular}{|c|c|c|c|}
\hline \multirow[b]{2}{*}{ Kelompok } & \multicolumn{2}{|c|}{$\begin{array}{c}\text { Kolmogorov- } \\
\text { Smirnov }^{\mathrm{a}}\end{array}$} & \multirow{2}{*}{$\begin{array}{l}\text { Shapiro-Wilk } \\
\text { Statistic df Sig. }\end{array}$} \\
\hline & Statistic Df & Sig. & \\
\hline Nilai eksperimen & .16429 & .044 & .89129.006 \\
\hline Kontrol & $.165 \quad 29$ & .041 & .927 29.045 \\
\hline
\end{tabular}

a. Lilliefors Significance Correct

Dari tabel 1. dapat disimpulkan bahwa, secara umum pembelajaran menggunakan perangkat pembelajaran discovery learning dapat meningkatkan berfikir kritis siswa dan lebih baik dari bahan ajar yang digunakan di sekolah.

b. Uji Homogenitas

\section{Tabel 2}

\begin{tabular}{l|l|r|r}
\hline & & \multicolumn{2}{|c}{$\begin{array}{c}\text { Levene's Test for Equality } \\
\text { of Variances }\end{array}$} \\
\hline & \multirow{2}{*}{ F } & \multicolumn{2}{|c}{ Sig. } \\
\hline \multirow{2}{*}{ Nilai } & $\begin{array}{l}\text { Equal variances } \\
\text { assumed }\end{array}$ & 7.115 & .010 \\
\cline { 2 - 3 } & $\begin{array}{l}\text { Equal variances not } \\
\text { assumed }\end{array}$ & & \\
\hline
\end{tabular}

Berdasarkan tabel output SPSS versi $16 \mathrm{di}$ atas, menunjukkan bahwa sig. padaa kolom Levene's Test for Equality of Variances adalah sebesar 0,010. Jika dibandingkan dengan $\alpha=0,05$, maka sig. $=0,010>\alpha=$ 0,05 sehingga berdasarkan kaidah penolakan hipotesis diputuskan bahwa terima $H_{0}$. Hal ini berarti bahwa varians kemampuan pengerjaan soal tes kelas eksperimen dan kelas kontrol sama atau homogen.

Berdasarkan data-data yang diuraikan tersebut maka dapat disimpulkan bahwa pembelajaran menggunakan perangkat 
pembelajaran dengan model discovery learning mampu meningkatkan aspek kognitif siswa melampaui batas ketuntasan belajar yang ditentukan sebelumnya sebesar $75 \%$ dan dinyatakan efektif.

Hasil-hasil di atas menunjukkan peningkatan nilai pada aspek semua kelas. Nilai yang berbeda adalah tingkat peningkatan ketercapaian belajar pada semua kelas. Berdasarkan data-data tersebut dapat ditarik kesimpulan bahwa pembelajaran menggunakan perangkat pembelajaran dengan model discovery learning mampu meningkatkan hasil belajar siswa berupa aspek sikap, keterampilan dan kognitif siswa. Peningkatan yang terjadi pada kelas uji coba dan kelas eksperimen terbukti lebih besar dibandingkan kelas kontrol.

\section{SIMPULAN}

Persoalan yang terjadi di lapangan kebanyakan pembelajarannya terpusat pada guru dan kurang aktifnya siswa dalam berfikir kritis dapat diminimalisir dengan menggunakan perangkat pembelajaran menggunakan discovery learning hal ini dapat dilihat dengan meningkatnya hasil belajar siswa. Hasil pengembangan perangkat pembelajaran dengan model discovery learning untuk meningkatkan berfikir kritis siswa. Hasil uji coba perangkat dan pelaksanaan pembelajaran menunjukkan bahwa pembelajaran IPS dengan model discovery learning untuk meningkatkan kualitas pembelajaran dengan menggunakan penilaian hasil belajar yang dikembangkan efektif.

DAFTAR PUSTAKA

Arikunto, S. 2009. Dasar-dasar Evaluasi Pendidikan. Jakarta: PT Bumi Aksara.

Azwar, S. 2013. Reliabilitas dan Validitas. Yogyakarta: Pustaka Pelajar.

Hamalik, O. 2008.Kurikulum \& Pembelajaran.Jakarta: Sinar Grafika

Hobri, 2010. Metode Penelitian Pengembangan. Jember: Pena Salsabila.

Dwijiastuti, MG. 2008. Inovasi Pembelajaran. Surakarta: UNS press.

Jihad, A. \& Haris, A. Evaluasi Pembelajaran. Yogyakarta: Multi Pressindo.

Mudyahardjo, R. 2008. Pengantar Pendidikan. Jakarta: PT RajaGrafindo Persada.

Sugiyono. 2009. Metode Penelitian kuantitatif, kualitatif dan $R \& D$. Bandung: Alfa Beta

Sugiyanto. 2009. Model- Model Pembelajaran Inovatif. Surakarta: Panitia Sertifikasi Guru Rayon 13 FKIP UNS Surakarta. 